\title{
The Antioxidant Enzymatic Activity of Date Palm Seedlings Under Abiotic Drought Stress
}

\author{
Mohammed I Sakran ${ }^{1,2}$, Haddad A El Rabey, ${ }^{1,3}$, Yaaser Q Almulaiky ${ }^{4,5}$, Mohammed A Al-Duais ${ }^{1,6}$, \\ Mohamed Elbakry ${ }^{1,2}$, Uzma Faridi*1
}

${ }^{1}$ Faculty of Science, University of Tabuk, Tabuk, KSA

${ }^{2}$ Biochemistry Section, Chemistry Department, Faculty of Science, Tanta University, EGYPT.

${ }^{3}$ Bioinformatics Department, Genetic Engineering and Biotechnology Institute, University of Sadat City, EGYPT.

${ }^{4}$ Chemistry Department, Faculty of Science, Taiz University, YEMEN.

${ }^{5}$ Chemistry Department, Faculty of Science, Jeddah University, Jeddah, KSA.

${ }^{6}$ Department of Chemistry, Faculty of Science, Ibb University, Ibb, YEMEN

\begin{abstract}
Objective: the present research was focused to evaluate the date palm resistance to osmotic stress exerted by three concentrations of poly ethylene glycol 6000 in three months seedlings as reflected by the change in phenolic and flavonoid content and the activity of catalase, peroxidase and polyphenol oxidase. Materials and Methods: The phenolic and flavonoid content and the target enzyme's activity was estimated at four time points; $0,1,3,7$ days. Results and Discussion: The phenolic and flavonoid content as well as the activity of catalase, peroxidase and polyphenol oxidase were increased by increasing the poly ethylene glycol and the treatment period. Conclusion: Phenolic and flavonoids are non-enzymatic antioxidants with high scavenging potential to the free radical produced from the oxidative stress resulted from the drought tolerance in date palm seedlings. In addition, the increase in the enzymatic activity of catalase, peroxidase and polyphenol oxidase under drought stress is very important to get rid of the free radicals and the reactive oxygen species.
\end{abstract}

Key words: Date palm, Phenol, Flavonoid, Catalase, Peroxidase, Polyphenol oxidase.

\section{INTRODUCTION}

Phoenix dactylifera L. (date palm) belongs to the genus Phoenix of (family Arecaceae). It has high economic value worldwide especially in the Middle East Countries and North Africa. Its place of origin is probably around Iraq. ${ }^{1}$

Date palm tree is drought tolerant, so it can tolerate the substantial water deficit in the soil or in the atmosphere, which is the constraint to crop productivity and yield stability worldwide. ${ }^{2}$ Drought affects a variety of vital physiological and biochemical processes in plants that cause a reduced growth and consequently a reduced final crop yield. ${ }^{3,4,5}$

Al-Khayri and A-Bahrany. ${ }^{6}$ stated that water availability is one of the principal limitations of crop production, particularly in the arid and semiarid regions where date palm is predominantly grown.

Due to its huge size, most physiological studies on date palm trees are achieved on seedling which originated from seed or tissue culture. ${ }^{3,4,7,8}$ Al-Ka'aby and Abdul-Qadir. ${ }^{7}$ studied the effect of water stress on callus induction from shoot tips of date palm (Phoenix dactylifera L.) cv. Bream cultured in vitro. Saidi et al. ${ }^{9}$ stated that brittle leaf disease induces an oxidative stress and decreases the expression of manganese-related genes in date palm (Phoenix dactylifera L.).

$\mathrm{Al}-$ Senaidy and $\mathrm{Ismae}^{10}$ purified and characterized peroxidase from date palm leaves and suggested that it could be a promising tool for applications in different analytical
Submission Date: 01-10-2017 Revision Date: 05-12-2017; Accepted Date: 08-01-2018

DOI: 10.5530/ijper.52.3.51 Correspondence:

Dr. Uzma Faridi,

Assistant Professor, Department of Biochemistry Tabuk University, SAUDI ARABIA.

Phone: 966541848745

E-mail: ufaridi@ut.edu.sa

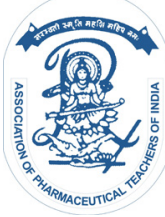

www.ijper.org 
determinations as well as for treatment of industrial effluents at low cost.

Date palm callus cultures exhibiting enhanced tolerance to salinity by exposure to $\mathrm{NaCl}$, potassium chloride $(\mathrm{KCl})$ and calcium chloride $(\mathrm{CaCl} 2)$, and drought stress assessed in response to varying concentrations of polyethylene glycol (PEG-8000) were in vitro selected. ${ }^{11}$

El Rabey et al. ${ }^{4,5}$ analyzed the proteome of date palm under drought and salinity stress condition and defined the genes responsible for drought and salinity tolerance. The response of date palm seedling against drought stress exerted by treatment with three levels of poly ethylene glycol at four-time points ( $0,1,3,7$ days) was studied in the light of phenolic and flavonoid content and the enzymatic activity of catalase, peroxidase and polyphenol oxidase.

\section{MATERIALS AND METHODS}

\section{Date palm seedlings}

Three months seedlings were obtained by germinating date palm seeds (Sagie cultivar) according to the protocol of Sané et al. ${ }^{8}$ as follows: seeds were sacrificed with concentrated sulfuric acid (96\%) for $5 \mathrm{~min}$, washed 5 times with sterile distilled water, followed by sterilization with $1 \%$ mercuric chloride for $3 \mathrm{~min}$, washed 5 times with sterile distilled water, and then imbibed for $48 \mathrm{~h}$ in distilled water. Seeds were sterilized a second time with calcium hypochlorite $(5 \%)$ for $4 \mathrm{~min}$ and then washed 4 times with sterile distilled water. The sterilized seeds were germinated between wet layers of tissue papers until the radical reached $1 \mathrm{~cm}$ and then transferred to pots containing beet moss and irrigated with tap water until the age of 3 months. The three months-old seedlings were subjected to 3 different drought stress conditions using polyethylene glycol 6000 (PEG): 6.9\%, 13.95\% and $27.5 \%$ of PEG. Samples were harvested at 4-time points, zero point at the start of the experiment, $24 \mathrm{~h}$, 3 days and 7 days.

\section{Chemicals}

Ammonium molybdate, 2,2'-azino-bis (3-ethylbenzothiazoline-6-sulfonic acid) (ABTS) and 1,1-Diphenyl2-picrylhydrazyl (DPPH)were purchased from Fluka (Germany). Hydrogen peroxide, guaiacol and catechol were purchased from Sigma (USA). Other Chemicals were purchased from Riedel-de-Haen (Germany).

\section{Preparation of methanol extract}

$10 \mathrm{ml}$ of $80 \%$ methanol were added to two $\mathrm{g}$ of date palm leaf powder, extracted by shaking at $150 \mathrm{rpm}$ and $25^{\circ} \mathrm{C}$ for $24 \mathrm{~h}$, and then filtered through Whatmann filter paper no. 1.

\section{Estimation of total flavonoid content}

The modified colorimetric method described by Zhishenet and team. ${ }^{12}$ was used in estimation of the total flavonoid content. In this method, catechin was used as a standard for estimation of total flavonoid content. $250 \mathrm{ml}$ of the standard solution (methanol extract) was mixed with $1.25 \mathrm{ml}$ distilled water and $75 \mathrm{~m}$ of $5 \% \mathrm{NaNO}_{2}$ solution. The mixture was combined with $150 \mathrm{ml}$ of $10 \% \mathrm{AlCl}_{3}$ solution after standing for 6 min. A $0.5 \mathrm{ml}$ of $1 \mathrm{M} \mathrm{NaOH}$ and $275 \mathrm{ml}$ distilled water was added to the mixture after waiting for $5 \mathrm{~min}$. The absorbance was calorimetrically measured at $510 \mathrm{~nm}$. The total flavonoid content was then quantified using the calibration curve obtained by measuring the absorbance of known concentrations of catechin. The obtained values are expressed as $\mathrm{mg}$ catechin equivalent (CE)/g tissues.

\section{Determination of total phenolic content}

The method of Velioglu et al. ${ }^{13}$ was used in the estimation of the total phenolic content. In this method, a $50 \mathrm{ml}$ of the methanol extract was mixed with $850 \mathrm{ml}$ of methanol and $100 \mathrm{ml}$ of Folin-Ciocalteu reagent, and then allowed to stand for $5 \mathrm{~min}$ at room temperature. After that, a $50 \mathrm{ml}$ of $20 \%$ sodium carbonate was added and allowed to react with the mixture for $30 \mathrm{~min}$, and then the absorbance was measured at $750 \mathrm{~nm}$. The total phenolic content could be calculated from the calibration curve obtained by measuring the absorbance of known concentrations of gallic acid. The obtained total phenolic content is expressed as $\mathrm{mg}$ gallic acid equivalent $(\mathrm{GAE}) / \mathrm{g}$ tissues.

\section{Antioxidants assay \\ Radical cation decolorization assay}

The ABTS (2,2'-azino-bis (3-ethylbenzo-thiazoline6-sulfonic acid) forms a relatively stable free radical, which decolorizes in its non-radical form. The scavenging activity of $\mathrm{ABTS}^{\bullet+}$ was determined according to the method of Re et al. ${ }^{14}$ ABTS $^{\cdot+}$ was obtained by the reaction of $7 \mathrm{mM}$ ABTS in $\mathrm{H}_{2} \mathrm{O}$ with $2.45 \mathrm{mM}$ potassium persulfate and stored in dark at room temperature for $16 \mathrm{~h}$. Dilution of $\mathrm{ABTS}^{\cdot+}$ was achieved to give an absorbance of $0.750 \pm 0.025$ at $734 \mathrm{~nm}$ in $0.1 \mathrm{M}$ sodium phosphate buffer ( $\mathrm{pH}$ 7.4). After that, $1 \mathrm{ml}$ of ABTS $^{\bullet+}$ solution was added to the crude methanol extract. The absorbance was measured $1 \mathrm{~min}$ after mixing. The percentage of radical scavenging was calculated in relation to a blank containing no scavenger. In addition, the 
extent of decolorization was calculated as the percentage reduction of absorbance. The scavenging capability of test compounds was calculated using the following equation:

$$
\text { ABTS }+ \text { scavenging }(\%)=\frac{\text { OD control }- \text { OD sample }}{\text { OD control }} \times 100
$$

The results were plotted by stetting the $\%$ of scavenging activity against the concentration of the sample. The inhibition concentration $\left(\mathrm{IC}_{50}\right)$ is the amount of crude methanol extract required for $50 \%$ of free radical scavenging activity. In addition, the $\mathrm{IC}_{50}$ value was calculated from the curve as the antioxidant concentration required for providing $50 \%$ free radical scavenging activity.

\section{DPPH radical scavenging activity}

The scavenging activity free radical of the crude methanol extract was determined following the method of Ao et al. ${ }^{15}$ using 2,2-diphenyl-1-picrylhydrazyl (DPPH). $100 \mu \mathrm{l}$ of the methanol extracts were added to $900 \mu \mathrm{l}$ of freshly prepared $0.1 \mathrm{mM}$ DPPH methanol solution. Methanol was used as a control (an equal amount). It was incubated in dark for $30 \mathrm{~min}$ at room temperature, and then the absorbance was measured at $517 \mathrm{~nm}$.

The activity of scavenging percentage was calculated as follows:

DPPH radical scavenging $(\%)=\frac{\text { OD control }- \text { OD sample }}{\text { OD control }} \times 100$

The results were plotted by setting the $\%$ of scavenging activity against the concentration of the sample. The $\mathrm{IC}_{50}$ value was calculated from the curve as the antioxidant concentration required for providing $50 \%$ free radical scavenging activity.

\section{Determination of antioxidant enzymes activity Preparation of the crude extract}

One $\mathrm{g}$ of milled date palm leaf was homogenized in $20 \mathrm{mM}$ Tris- $\mathrm{HCl}$ buffer ( $\mathrm{pH}$ 7.2) contained $0.1 \mathrm{M} \mathrm{NaCl}$ and 2\% Triton-x100 using homogenizer. The homogenate was centrifuged at $10,000 \mathrm{rpm}$ for $15 \mathrm{~min}$ at $4^{\circ} \mathrm{C}$. The supernatant was stored at $-20^{\circ} \mathrm{C}$ for further analysis.

\section{Estimation of catalase activity}

Catalase activity was determined according to the method of Bergmeyer. ${ }^{16} 2.5 \mathrm{ml}$ of the substrate solution was made up to $25 \mathrm{mM} \mathrm{H}_{2} \mathrm{O}_{2}$ with $75 \mathrm{mM}$ sodium phosphate buffer ( $\mathrm{pH} 7.0)$ and crude extract. The decrease in absorbance at $240 \mathrm{~nm}$ and $25^{\circ} \mathrm{C}$ was recorded for $1 \mathrm{~min}$. A unit of catalase activity was defined as the amount of the enzyme that causes a change of 0.1 in absorbance per min under standard assay conditions.

\section{Estimation of peroxidase activity}

The peroxidase activity was estimated according to the method of Miranda et al. ${ }^{17} \mathrm{In} 1 \mathrm{ml}$ tube, the least amount of crude extract $(100 \mu \mathrm{l})$ was mixed with $(900 \mu \mathrm{l})$ $8 \mathrm{mM} \mathrm{H}_{2} \mathrm{O}_{2}, 40 \mathrm{mM}$ guaiacol, $50 \mathrm{mM}$ sodium acetate buffer ( $\mathrm{pH}$ 5.5). The absorbance was measured at $470 \mathrm{~nm}$ after $1 \mathrm{~min}$ due to guaiacol oxidation. A unit of peroxidase activity is defined as the amount of enzyme which increased the O.D. 1.0 per min under standard assay conditions.

\section{Estimation of polyphenoloxidase activity}

The activity of polyphenol oxidase was assayed with catechol as a substrate according to the spectrophotometric procedure of Jiang et al. ${ }^{18} 100 \mu \mathrm{l}$ of the enzyme solution was rapidly added to $900 \mu \mathrm{l}$ of $40 \mathrm{mM}$ catechol solution prepared in $0.01 \mathrm{M}$ sodium phosphate buffer (pH 6.8). The increase in absorbance at $400 \mathrm{~nm}$ and $25^{\circ} \mathrm{C}$ was recorded for $3 \mathrm{~min}$. A unit of polyphenol oxidase is defined as the amount of the enzyme that causes a change of 0.1 in absorbance per min.

\section{Statistical analysis}

The standard error, the mean value and all curves were calculated and plotted using Origin 8 program.

\section{RESULTS}

Table 1 show that the total phenolic (gallic acid equivalent) and flavonoid (catechin equivalent) content were increased by increasing the PEG concentration and the exposure period compared to the control.

\section{Antioxidant activity of GAE of date palm leaf on reduction of DPPH and ABTS radical scavenging.}

The antioxidant activity of gallic acid equivalent as revealed by reduction of DPPH and ABTS radical scavenging of drought stressed date palm is shown in Table 2 and Figure 1 and Figure 2, respectively.

The free radical scavenging activity of DPPH and ABTS is reduced by increasing PEG concentration and increasing exposure time as revealed from the mean value of the correlation coefficients $\left(R^{2}\right)$ between phenolic contents and DPPH and ABTS scavenging activity, respectively and the $\mathrm{IC}_{50}$.

\section{The activity of catalase in date palm leaf under drought stress}

Table 3 and Figure 3 (A) show the activity of catalase in the leaf of date palm under stress using the three concentration of PEG under study. 


\begin{tabular}{|c|c|c|c|}
\hline Days & PEG & Phenolic content mg GAE/ g tissue & $\begin{array}{l}\text { Flavonoid content } \\
\mathrm{mg} \mathrm{CE} / \mathrm{g} \text { tissue }\end{array}$ \\
\hline control & 0 & $3.4 \pm 0.024$ & $0.99 \pm 0.002$ \\
\hline \multirow[t]{3}{*}{1 day } & $6.9 \%$ & $3.57 \pm 0.032$ & $1.19 \pm 0.003$ \\
\hline & $13.96 \%$ & $3.86 \pm 0.046$ & $1.28 \pm 0.002$ \\
\hline & $27.5 \%$ & $3.94 \pm 0.041$ & $1.36 \pm 0.004$ \\
\hline \multirow[t]{3}{*}{3 days } & $6.9 \%$ & $4.01 \pm 0.053$ & $1.48 \pm 0.003$ \\
\hline & $13.96 \%$ & $4.05 \pm 0.055$ & $1.52 \pm 0.004$ \\
\hline & $27.5 \%$ & $4.33 \pm 0.052$ & $1.56 \pm 0.005$ \\
\hline \multirow[t]{3}{*}{7 days } & $6.9 \%$ & $4.56 \pm 0.053$ & $1.59 \pm 0.003$ \\
\hline & $13.96 \%$ & $4.74 \pm 0.056$ & $1.7 \pm 0.002$ \\
\hline & $27.5 \%$ & $4.89 \pm 0.054$ & $1.74 \pm 0.0021$ \\
\hline
\end{tabular}

$G A E$, gallic acid equivalent, $C E$, catechin equivalent. Values are presented as means $\pm S D(n=5)$, values are presented as means $\pm S D(n=5)$.

\begin{tabular}{|c|c|c|c|c|c|}
\hline \multirow[t]{2}{*}{ Days } & \multirow[b]{2}{*}{ PEG } & \multicolumn{2}{|c|}{ DPPH } & \multicolumn{2}{|c|}{ ABTS } \\
\hline & & R2 & $\mathrm{IC}_{50}(\mu \mathrm{g}$ GAE) & R2 & $\mathrm{IC}_{50}(\mu \mathrm{g}$ GAE) \\
\hline control & 0 & 0.982 & $23.1 \pm 0.32$ & 0.955 & $8 \pm 0.34$ \\
\hline \multirow[t]{3}{*}{1 day } & $6.9 \%$ & 0.996 & $11.58 \pm 0.18$ & 0.989 & $7.19 \pm 0.30$ \\
\hline & $13.96 \%$ & 0.985 & $11.4 \pm 0.21$ & 0.993 & $6.45 \pm 0.26$ \\
\hline & $27.5 \%$ & 0.981 & $11 \pm 0.16$ & 0.997 & $5.81 \pm 0.31$ \\
\hline \multirow[t]{3}{*}{3 days } & $6.9 \%$ & 0.976 & $9.864 \pm 0.15$ & 0.989 & $4.78 \pm 0.28$ \\
\hline & $13.96 \%$ & 0.9969 & $9.75 \pm 0.17$ & 0.973 & $4.25 \pm 0.14$ \\
\hline & $27.5 \%$ & 0.947 & $9.24 \pm 0.18$ & 0.999 & $3.82 \pm 0.10$ \\
\hline \multirow[t]{3}{*}{7 days } & $6.9 \%$ & 0.941 & $8.468 \pm 0.075$ & 0.990 & $2.7 \pm 0.094$ \\
\hline & $13.96 \%$ & 0.918 & $7.34 \pm 0.10$ & 0.992 & $1.72 \pm 0.096$ \\
\hline & $27.5 \%$ & 0.9238 & $7.049 \pm 0.12$ & 0.993 & $1.4 \pm 0.089$ \\
\hline
\end{tabular}

$I C_{50}$ : is the inhibition concentration as $\mu \mathrm{g}$ GAE of the test sample that decreases $50 \%$ of DPPH and ABTS radicals. Values are presented as means \pm SD $(n=5)$. $R^{2}$ are the correlation coefficients between phenolic contents and DPPH and ABTS scavenging activity, respectively.

\section{The activity of peroxidase in date palm leaf under drought stress}

Table 4 and Figure 3 (B) show the change in the activity of peroxidase in the leaf of date palm under stress using the three concentration of PEG $(6.9 \%, 13.9 \%$ and $27.5 \%$ ) under study. The activity of peroxidase was increased by increasing the PEG concentration and the treatment period.

\section{The activity of polyphenoloxidase in date palm leaf under drought stress}

Table 5 and Figure 3 (C) show the change in the activity of polyphenoloxidase in the leaf of date palm under stress using the three concentration of PEG (6.9\%, $13.9 \%$ and $27.5 \%$ ) under study. The activity of polyphenoloxidase was increased by increasing the PEG concentration and the period of treatment.

\section{DISCUSSION}

The current study showed that the activity of catalase, peroxidase and polyphenol oxidase in date palm leaves was increased with the increase in PEG concentration due to the increase of osmotic stress, as well as the increase in the exposure period to drought stress. This result is consistent with that of Huseynova ${ }^{19}$ and El Rabey et al. ${ }^{5}$ on wheat and Kar and Mishra. ${ }^{20,21,22}$ on rice. This result also agrees with that of Wang ${ }^{23}$ who noticed the increase in the antioxidant enzyme activity during germination of alfalfa under salt and drought stresses subjected to drought stress.

The osmoregulation is considered a physiological adaptation under stress condition, which occurs by reducing cellular water potential via accumulation of a variety of organic and inorganic solutes in the cell and increase 

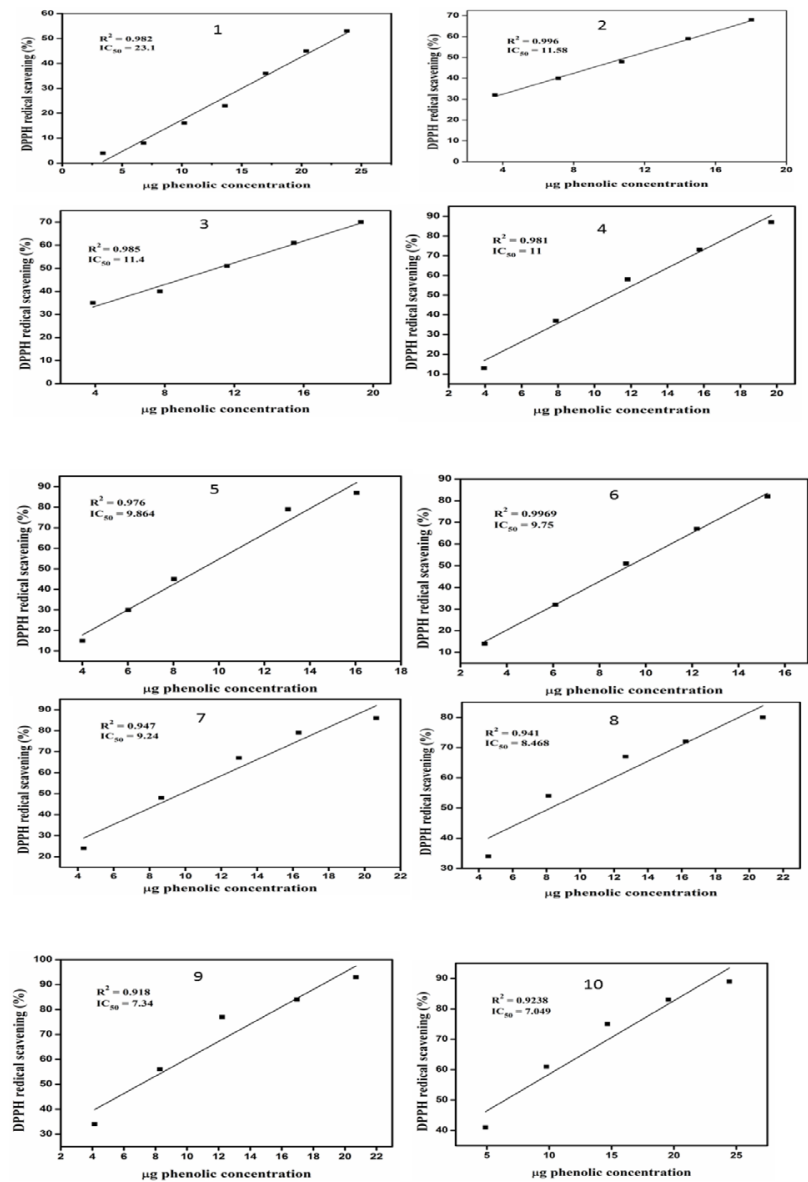

Figure 1: Correlation between concentrations of phenolic compounds of date palm leaf, and their antioxidant activity as determined by DPPH assay.1: control; 2: 1day,6.9\% PEG ; 3: 1day,13.9\% PEG; 4: 1day,27.5\% PEG ; 5: 3days,6.9\% PEG; 6 : 3days,13.9\% PEG; 7: 3days,27.5\% PEG; 8: 7days,6.9\% PEG; 9: 7days,13.9\% PEG; 10: 7days,27.5\% PEG.

\begin{tabular}{|c|c|c|c|}
\hline Catalase & $\begin{array}{c}6.9 \% \text { PEG } \\
\text { unit/g/min }\end{array}$ & $\begin{array}{c}13.95 \% \text { PEG } \\
\text { unit } / \mathrm{g} / \mathrm{min}\end{array}$ & $\begin{array}{l}27.5 \% \text { PEG } \\
\text { unit } / \mathrm{g} / \mathrm{min}\end{array}$ \\
\hline control & 54 & 54 & 54 \\
\hline 1 day & 59 & 62 & 69 \\
\hline 3 days & 65 & 71 & 77 \\
\hline 7 days & 78 & 80 & 83 \\
\hline
\end{tabular}

Table 4: Activity of peroxidase under drought stress exerted by different concentrations of PEG $(6.9 \%, 13.9 \%$ and $27.5 \%)$ for 1,3 and 7 days.

\begin{tabular}{|c|c|c|c|}
\hline peroxidase & $\begin{array}{c}\mathbf{6 . 9} \% \text { PEG } \\
\text { unit/g/min }\end{array}$ & $\begin{array}{c}\mathbf{1 3 . 9 5 \%} \text { PEG } \\
\text { unit/g/min }\end{array}$ & $\begin{array}{c}\mathbf{2 7 . 5 \%} \text { PEG } \\
\text { unit/g/min }\end{array}$ \\
\hline Control & 118 & 118 & 118 \\
\hline 1 day & 119 & 124 & 132 \\
\hline 3 days & 123 & 137 & 148 \\
\hline 7 days & 135 & 146 & 159 \\
\hline
\end{tabular}
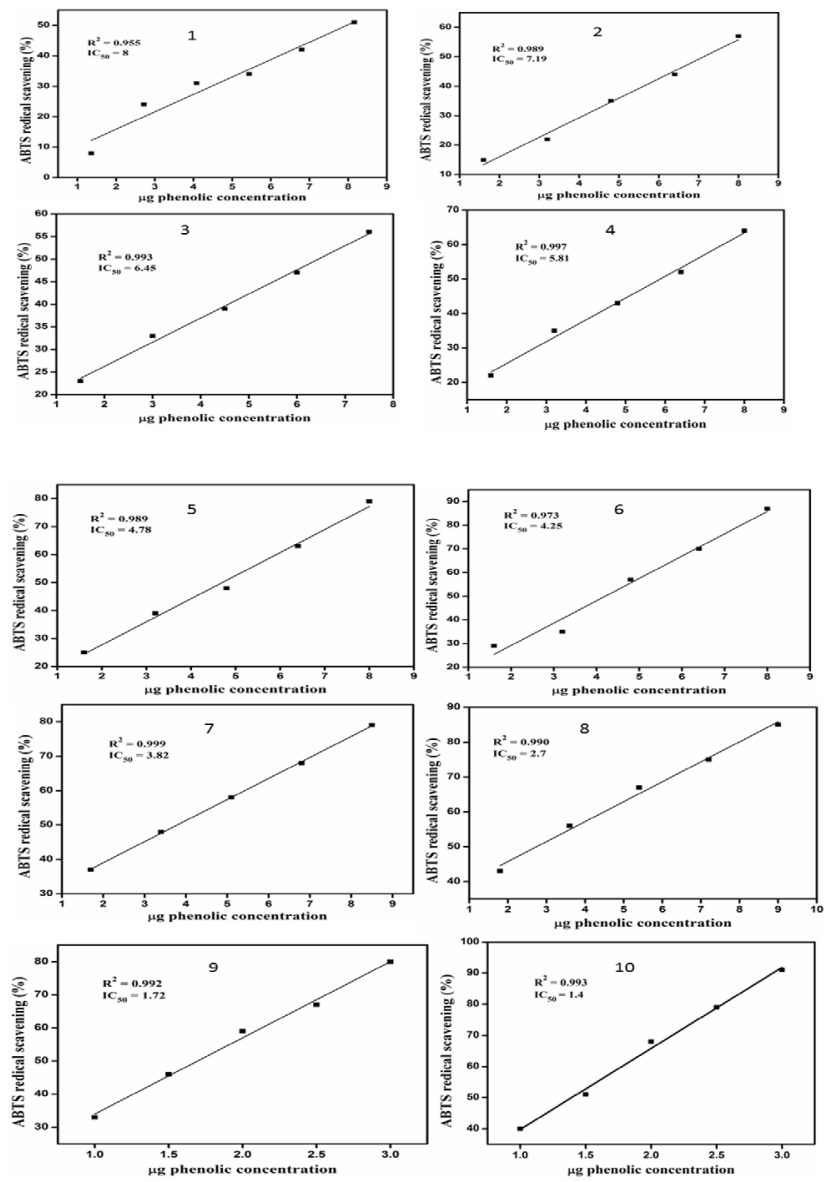

Figure 2: Correlation between concentrations of phenolic compounds of date palm leaf, and their antioxidant activity as determined by ABTS assay.1: control; 2: 1day,6.9\% PEG ; 3: 1day,13.9\% PEG; 4: 1day,27.5\% PEG ; 5: 3days,6.9\% PEG; 6: 3days,13.9\% PEG; 7: 3days,27.5\% PEG; 8: 7days,6.9\% PEG; 9: 7days, 13.9\% PEG; 10: 7days,27.5\% PEG.
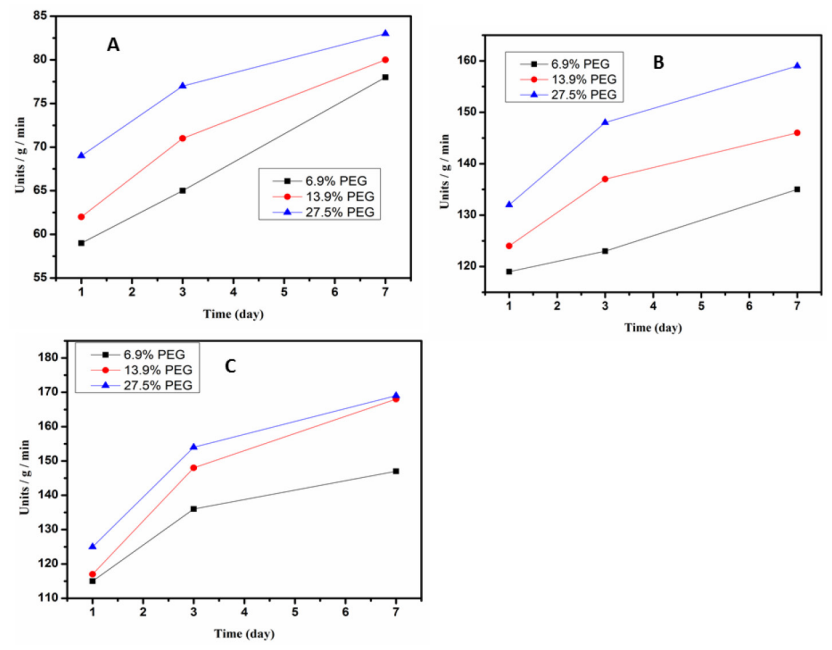

Figure 3: The activity of catalase (A), peroxidase (B) and poly phenol oxidase (C) under drought stress exerted by different concentrations of PEG $(6.9 \%, 13.9 \%$ and $27.5 \%)$ for 1,3 and 7 days. 
Table 5: Activity of polyphenoloxidase under drought stress exerted by different concentrations of PEG (6.9\%, $13.9 \%$ and $27.5 \%)$ for 1,3 and 7 days.

\begin{tabular}{|c|c|c|c|}
\hline Polyphenoloxidase & $\begin{array}{c}\mathbf{6 . 9} \% \text { PEG } \\
\text { unit/g/min }\end{array}$ & $\begin{array}{c}\mathbf{1 3 . 9 5 \%} \\
\text { unit/g/min }\end{array}$ & $\begin{array}{c}\mathbf{2 7 . 5} \% \\
\text { unit/g/min }\end{array}$ \\
\hline Control & 106 & 106 & 106 \\
\hline 1 day & 115 & 117 & 125 \\
\hline 3 days & 136 & 148 & 154 \\
\hline 7 days & 147 & 168 & 169 \\
\hline
\end{tabular}

the oxidative stress. ${ }^{2,5}$ Under drought stress, plants are capable of taking up water from a low water potential medium to sustain normal or near normal physiological processes necessary for growth and development. ${ }^{2}$

The increase in the activity of the target enzymes under drought stress in the current study is in agreement with the theory says that plants produce a variety of antioxidants that counteract the generation of reactive oxygen species (ROS) in response to drought stress. ${ }^{21,22,23}$ Phenol and flavonoids of date palm leaves under study were increased as a result of increasing the concentration of PEG and the treatment period. These two compounds represent the non-enzymatic antioxidants scavenging the free radicals resulted from the oxidative stress exerted by PEG treatment. ${ }^{24}$ The increase in phenolic and flavonoids content and the enzymatic activity of catalase, peroxidase and polyphenol oxidase together with other responses and adaptations enable plants to sustain growth and development under drought condition. ${ }^{2,5}$ In addition, Proteome analysis of date palm under drought stress showed that drought stress elicits the genes responsible for photosynthesis. ${ }^{3,4}$ The phenolic and flavonoids content and the enzymatic activity of catalase, peroxidase and polyphenol oxidase were increased by the increase of PEG concentration and the treatment period. Phenolic and flavonoids are non-enzymatic antioxidants with high scavenging potential to the free radical produced by the oxidative stress resulted from the drought tolerance in date palm seedlings. Moreover, the increase in the enzymatic activity of catalase, peroxidase and polyphenol oxidase under drought stress is also important to get rid of the free radicals and the reactive oxygen species resulted from drought stress..$^{25,26,27}$

\section{CONCLUSION}

Phenolic and flavonoids are considered to be the non-enzymatic antioxidants with high antioxidant potential and they scavenge the free radical produced during the oxidative stress in the drought- stressed date palm seedlings. Not only the phenolics and flavonoids level but also other antioxidative enzymes like catalase, peroxidase and polyphenol oxidase significant increase which prevent the plant from oxidative damage.

\section{CONFLICT OF INTEREST}

No conflict of interest is declared.

\section{ACKNOLWEDGEMENT}

Authors are grateful to head of the department, Department of Biochemistry, University of Tabuk, Saudi Arabia for his support.

\section{ABBREVIATIONS}

DPPH:1,1-Diphenyl- 2-picrylhydrazyl; ROS: Reactive oxygen species; PEG: polyethylene glycol 6000; GAE: Gallic acid equivalent, CE: Catechin equivalent; ABTS: Ammonium molybdate, 2,2'-azino-bis (3-ethylbenzothiazoline-6-sulfonic acid).

\section{REFERENCES}

1. Morton J. Date. p. 5-11. In: Fruits of warm climates. Purdue University. Center for New Crops and Plants Produc1987.

2. Ashraf M, Akram NA, Al-Qurainy F, Foolad MR. (2011) Chapter five - Drought Tolerance: Roles of Organic Osmolytes, Growth Regulators, and Mineral Nutrients. In 'Advances in Agronomy'. 2011;1(1):249-96. (Ed. LS Donald) pp. 249-96. (Academic Press). http://www.sciencedirect.com/science/article/pii/ B9780123876898000023.

3. El Rabey HA, Al-Malki AL, Abulnaja KO, Rohde W. Proteome Analysis for understanding abiotic stress (salinity and drought) tolerance in date palm (Phoenix dactylifera L.). Int. J. Genom. 2015, 2015, 1-11.

4. El Rabey HA, Al-Malki AL, Abulnaja KO. Proteome Analysis of Date Palm (Phoenix dactyliferaL.) under Severe Drought and Salt Stress. International Journal of Genomics. 2016. Article ID 7840759, 8 pages.

5. El Rabey Haddad A, Almutairi Fahad M, Sakran Mohamed I, Zamzami Mazin A, Al-Sieni Abdulbasit I. Molecular and enzymatic response to drought stress in wheat (Triticumaestivum L.). International Journal of Pharmaceutical Research and Allied Sciences. 2017;6(1):81-94.

6. Al-Khayri JM. Al-Bahrany AM. Growth, water content, and proline accumulation 1n drought- stressed callus of date palm. Bio. Plant. 2004:48(1):105-8.

7. Al-Ka'aby HK and Abdul-Qadir LH. Effect of water stress on callus induction from shoot tips of date palm (Phoenix dactylifera L.) cv. Bream cultured in vitro. Basrah journal for date palm research. 2011;10(2).

8. Djibril S, Mohamed OK, Diaga D, Diégane D, Abaye BF, Maurice S, et al. Growth and development of date palm (Phoenix dactylifera L.) seedlings under drought and salinity stresses. African Journal of Biotechnology. 2005;4(9):968-72.

9. Saidi MN, Jbir R, Ghorbel I, Namsi A, Drira N, Gargouri-Bouzid R. Brittle leaf disease induces an oxidative stress and decreases the expression of manganese-related genes in date palm (Phoenix dactylifera L.). Plant Physiology and Biochemistry. 2012;50:1-7.

10. Al-Senaidy AM, Ismael MA. Purification and characterization of membranebound peroxidase from date palm leaves (Phoenix dactylifera L.). Saudi Journal of Biological Sciences. 2011;18:293-8.

11. Al-Khayri JM and Ibraheem Y. in vitro selection of abiotic stress tolerant date palm (Phoenix dactylifera L.): A review. Emir. J. Food Agric. 2014;26(11):921-33. 
12. Zhishen J, Mengcheng T, Jianming W. The determination of flavonoid contents in mulberry and their scavenging effects on superoxide radicals. Food Chemistry. 1999;64(4):555-9.

13. Velioglu YS, Mazza G, Gao L, Oomah BD. Antioxidant activity and total phenolics in selected fruits, vegetables, and grain products. Journal of agricultural and food chemistry. 1998;46(10):4113-7.

14. Re R, Pellegrini N, Proteggente A, Pannala A, Yang M, Rice-Evans C. Antioxidant activity applying an improved ABTS radical cationdecolorization assay. Free Rad Biol Med. 1999;26(9-10):1231-7.

15. Ao C, Li A, Elzaawely, AA, Xuan, TD and Tawata S. Evaluation of antioxidant and antibacterial activities of Ficusmicrocarpa L. fil. Extract. Food control. 2008;19(10):940-8.

16. Bergmeyer HU. Methods of Enzymatic Analysis. Volume 1, 2nd edition, Edited by Bergmeyer, HU, Academic press, New York. 1974;574-579.

17. Miranda MIV, Lahore HEMFA, Cascone O. Horseradish peroxidase extraction and purification by aqueous two-phase partition. Applied Biochemistry and Biotechnology. 1995;53(2):147-54.

18. Jiang YM, Zhang Z, Joyce DC, Ketsa S. Postharvest biology and handling of longan fruit (DimocarpuslonganLour.) Postharvest Bioliogy and Technology. 2002;26(3):241-52.

19. Huseynova IM. Photosynthetic characteristics and enzymatic antioxidant capacity of leaves from wheat cultivars exposed to drought, Biochim Biophys Acta. 2012;1817(8):1516-23.

20. Hariharan P, Palani M, Vaiyapuri M. An Evaluation of Antioxidant Potential of Flavonoid Eriodictyol in Isoproterenol-Induced Myocardial Infarction in Rats. Indian Journal of Pharmaceutical Education and Research. 2017;51(4):603-12.
21. Raslin A, Sathiya S, Babu CS, Rajkumar J. Attenuation of Oxidative Stress and Hepatotoxicity Induced By D-Galactosamine by a Polyherbal Formulation Ambrex-in vivo and in vitro Studies. Indian Journal of Pharmaceutical Education and Research. 2017;51(4):729-39.

22. Kar M, Mishra D. Catalase, peroxidase and polyphenol oxidase activities during rice leaf senescence, Pant physiol. 1976;57(2):315-9.

23. Wang WB, Kim YH, Lee HS, Kim KY, Deng XP, Kwak SS. Analysis of antioxidant enzyme activity during germination of alfalfa under salt and drought stresses, Plant Physiol. Biochem. 2009;47(7):570-7.

24. Jaleel AC, Sankar B, Murali PV, Gomathinayagam M, Lakshmanan, GA, Panneerselvam $\mathrm{R}$. Water deficit stress effects on reactive oxygen metabolism in Catharanthusroseus; impacts on ajmalicine accumulation. Colloids Surf $B$. 2008;62(1):105-11.

25. David AVA, Satyanarayana N, Parasuraman S, Bharathi S, Arulmoli R. Ameliorative effect of quercetin on methotrexate induced toxicity in sprague-dawley rats: A histopathological study. Indian J Pharm Educ Res. 2016;50:S200-8.

26. Rajendran, et al. Antioxidant Assay of Gold and Silver Nanoparticles from Edible Basidiomycetes Mushroom Fung Free Radicals and Antioxidants, 2017;7(2):137-42.

27. Bhaskaran M, Kenganora M, Santhepete MN, Hukkeri VI. Antioxidant Potential of a Toxic Plant Calotropis procera R.Br. Free Radicals and Antioxidants. 2017;7(2):143-51.

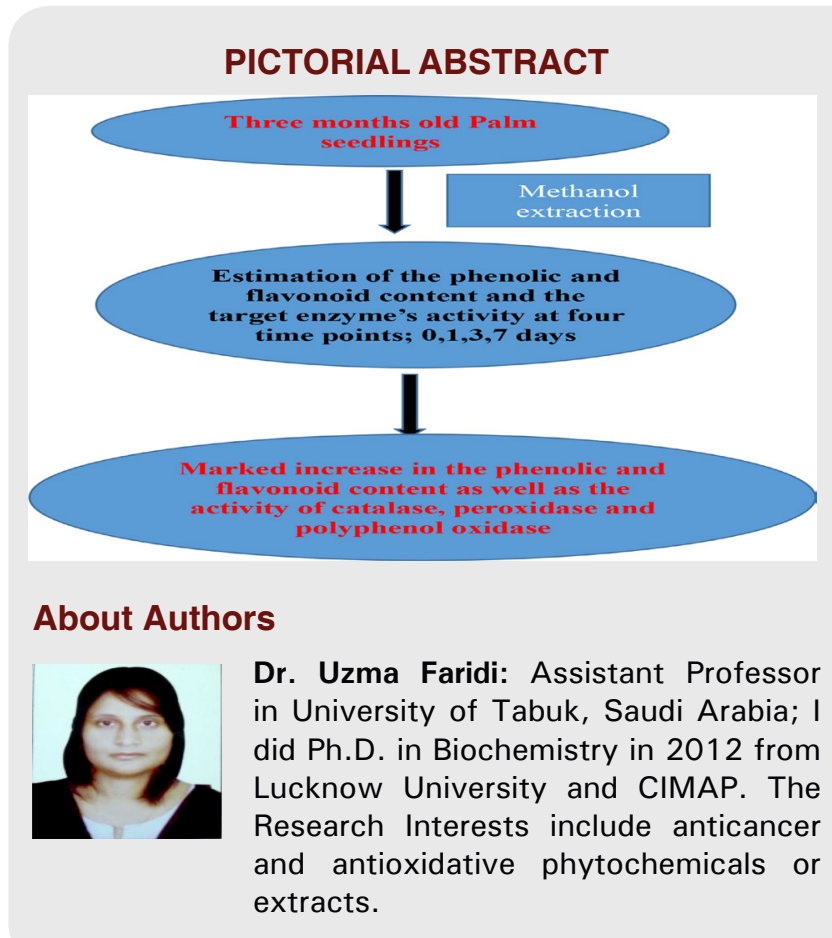

\section{SUMMARY}

- The present study was design to evaluate the antioxidative activity of date palm seedlings under abiotic drought stress conditions.

- For the antioxidant studies three months seedlings were obtained by germinating date palm seeds and different antioxidant enzymatic activities were carried out in the extract methanol extracts of the leaves. Total phenolics, catalase, peroxidase activity and polyphenoloxidase activity were performed.

- Phenolic and flavonoids, the non-enzymatic antioxidants with high scavenging properties resulted from the drought tolerance in date palm seedlings. In addition, the increase in the enzymatic catalase, peroxidase and polyphenol oxidase was present which play crucial role under drought stress.

Cite this article: Sakran MI, Rabey HE, Almulaiky YQ, Al-Duais MA, Elbakry M, Faridi U. The Antioxidant Enzymatic Activity of Date Palm Seedlings Under Abiotic Drought Stress. Indian J of Pharmaceutical Education and Research. $2018 ; 52(3): 442-8$. 